\title{
PENERAPAN MODEL PEMBELAJARAN KOOPERATIF TIPE SNOWBALL THROWING UNTUK MENINGKATKAN HASIL BELAJAR IPS SISWA KELAS V SDN 161 PEKANBARU
}

Anis Mahera*, Neni Hermita, Lazim N.

Pendidikan Guru Sekolah Dasar Fakultas Keguruan dan IImu Pendidikan Universitas Riau, Pekanbaru “anismahera08@yahoo.com

\section{ABSTRACT}

The background of this study was the low grade $V$ social studies learning outcomes of SDN 161 Pekanbaru with an average of 65.83. Therefore this study aims to improve social studies learning outcomes in class $V$. Research is Classroom Action Research (CAR) which consists of four stages, namely planning, implementation, observation and reflection. The subjects in this study were class V.C as many as 30 students consisting of 12 men and 18 women. The results showed that classical completeness in the first cycle was $63.33 \%$ which increased in the second cycle by $86.66 \%$. Teacher activities increased at each meeting, namely $70.83 \%, 79.16 \%, 83.33 \%$, and $87.5 \%$. Likewise, student activity experienced an increase in each of which was $58.33 \%, 66.66 \%, 79.16 \%$, and $87.5 \%$. The average basic score to the first cycle increased by $12.65 \%$ and the base score to the second cycle increases by $33.16 \%$. Based on the research that has been carried out, it can be concluded that the application of the cooperative learning model of the type of student facilitator and explaining can improve the learning outcomes of Social Sciences class V at SDN 161 Pekanbaru.

Keywords : cooperative learning model, snowball throwing type, social studies learning outcomes.

\section{PENDAHULUAN}

Pendidikan adalah usaha sadar dan terencana untuk mewujudkan suasana belajar dan proses pembelajaran agar peserta didik secara aktif mengembangkan potensi dirinya untuk memiliki kekuatan spiritual keagamaan, pengendalian diri, kepribadian, kecerdasan, akhlak mulia, serta keterampilan yang diperlukan dirinya, masyarakat, bangsa dan negara (UU No. 20 Tahun 2003 Pasal 1). Pendidikan mengandung pengertian suatu perbuatan yang disengaja untuk menjadikan manusia memiliki kualitas yang lebih baik.

A. Mahera, N. Hermita, \& Lazim. N, Penerapan Model Pembelajaran Kooperatif Tipe Snowball Throwing untuk Meningkatkan Hasil Belajar IPS Siswa Kelas V SDN 161 Pekanbaru 
Tanamir (Yusuf Irfan, dkk. 2017) Pendidikan adalah suatu upaya yang dilakukan untuk mempersiapkan peserta didik agar dapat memainkan perannya di masa depan sebagai manusia dengan pembangunan yang berkualitas bagi masyarakat dan negara.

IPS mempunyai peranan yang penting bagi siswa dalam memposisikan dirinya dalam berinteraksi baik dalam lingkungan keluarga, sekolah, dan masyarakat. Mata pelajaran IPS adalah salah satu mata pelajaran wajib yang diajarkan kepada siswa sekolah dasar. IPS berperan sebagai pendorong untuk saling pengertian dan persaudaraan antar umat manusia, selain itu juga memusatkan perhatiannya pada hubungan antar manusia dan pemahaman sosial.

Tujuan dari pembelajaran IPS di sekolah dasar adalah untuk mendidik dan memberi bekal kemampuan dasar kepada siswa untuk untuk mengembangkan diri sesuai dengan bakat, minat, kemampuan dan lingkungannya, serta sebagai bekal bagi siswa untuk melanjutkan pendidikan ke jenjang yang lebih tinggi.

Berdasarkan hasil observasi dan dokumentasi yang dilakukan penulis dengan Ibu Nurhasanah, S.Pd selaku wali kelas V SD Negeri 161 Pekanbaru Pekanbaru diperoleh data bahwa hasil belajar IPS siswa kelas $\mathrm{V}$ umunnya masih tergolong rendah, perhatikan dari data berikut: jumlah siswa kelas V.C sebanyak 30 siswa dengan KKM 75. Pada pelajaran IPS 12 siswa yang tuntas yaitu 40\% dan 18 siswa tidak tuntas yaitu $60 \%$ dengan jumlah rata-rata nilai siswa 65,66. Data diatas menggambarkan bahwa masih rendahnya siswa yang mencapai nilai ketuntasan.

Hal ini disebabkan karena; (1) Pembelajaran yang dilakukan guru tidak menerapkan model dalam pembelajaran, tanya jawab dan penugasan sehingga mengakibatkan kegiatan pembelajaran terbatas dan siswa cepat jenuh/bosan dalam kegiatan pembelajaran; (2) Guru tidak melibatkan siswa dalam proses pembelajaran; (3) Guru tidak menggunakan media dalam proses pembelajaran. Hal ini dapat dilihat permasalahan yang ditimbulkan adalah; (1) siswa kurang memahami materi yang diajakan oleh guru; (2) siswa tidak aktif dalam pembelajaran yang diberikan guru; (3) siswa tidak semangat dalam proses pembelajaran. Pembelajaran IPS dikembangkan untuk dapat meningkatkan 
keaktifan siswa dalam proses pembelajaran sehingga dapat meningkatkan hasil belajar.

Penelitian ini menggunakan Penelitian Tindakan Kelas (PTK) penelitian ini bertujuan untuk meningkatkan hasil belajar IPS siswa kelas V SD Negeri 161 Pekanbaru dengan menerapkan model kooperatif tipe snowball throwing. Menurut Arahman dalam Hamdayama Jumanta (2014) snowball throwing adalah suatu model pembelajaran yang diawali dengan pembentukan kelompok yang diwakili ketua kelompok untuk mendapat tugas dari guru, kemudian masing-masing siswa membuat pertanyaan di selembar kertas yang dibentuk seperti bola (kertas pertanyaan) lalu dilempar kesiswa lain. Siswa yang mendapat lembaran kertas harus menjawab pertanyaan dalam kertas yang diperoleh.

Sesuai dengan judul penelitian peneliti mengemukakan rumus masalah dalam penelitian ini "Apakah penerapan model pembelajaran Kooperatif Tipe Snowball Throwing dapat meningkatkan hasil belajar IPS siswa kelas V SD Negeri 161 Pekanbaru. Sesuai dengan rumusan masalah yang dikemukan diatas maka penelitian ini bertujuan untuk meningkatkan hasil belajar IPS kelas V SDN 161 Pekanbaru dengan menerapkan Model Pembelajaran Kooperatif Tipe Snowball Throwing" Manfaat penelitian bagi peneliti dan pembaca antara lain:

a. Dapat menjadi bahan masukan untuk peningkatan mutu pendidikan melalui pembelajaran inovatif

b. Dapat termotivasi dengan menggunakan model pembelajaran yang inovatif untuk meningkatkan pemahaman siswa.

c. Dapat meningkatkan semangat untuk mengikuti kegiatan pembelajaran dan dapat meningkatkan pemahamannya tentang materi pembelajaran

d. sebagai sumber pertimbangan bagi penelitian selanjutnya yang relevan.

Trianto (2010) berpendapat bahwa pembelajaran kooperatif merupakan sebuah kelompok strategi pembelajaran yang melibatkan siswa kerja secara kolaboratif untuk mencapai sebuah tujuan bersama, maka siswa akan mengembangkan keterampilan berhubungan dengan sesama manusia yang akan sangat bermanfaat bagi kehidupan di luar sekolah.

A. Mahera, N. Hermita, \& Lazim. N, Penerapan Model Pembelajaran Kooperatif Tipe Snowball Throwing untuk Meningkatkan Hasil Belajar IPS Siswa Kelas V SDN 161 Pekanbaru 
Sanjaya (Vidianawati Irna, dkk. 2014) mendefinisikan pembelajaran kooperatif sebagai model pembelajaran dengan menggunakan sistem mengelompokkan atau tim kecil, yaitu antara empat sampai enam orang yang mempunyai latar belakang kemampuan akademik, jenis kelamin, ras, atau suku yang berbeda (heterogen).

Model pembelajaran kooperatif dapat didefinisikan sebagai suatu pendekatan mengajar dimana murid bekerja sama diantara satu sama lain dalam kelompok belajar yang kecil untuk menyelesaikan tugas individu atau kelompok yang diberikan oleh guru (Isjoni, 2016).

Trianto (2010) terdapat enam langkah utama atau tahapan dalam pembelajaran yang menggunakan pembelajaran kooperatif. Langkah-langkah model pembelajaran kooperatif dapat dilihat pada tabel Langkah-langkah pembelajaran kooperatif dapat dilihat pada tabel 1:

\section{Tabel 1}

Langkah-langkah Model Pembelajaran Kooperatif

\section{Fase-fase}

Fase -1

Menyampaikan tujuan dan memotivasi siswa

Fase-2

Menyajikan informasi

Fase-3

Mengorganisasikan siswa ke dalam kelompok kooperatif

Fase-4

Membimbing kelompok bekerja dan belajar

Fase-5

Evaluasi

Fase-6

Memberikan penghargaan

\section{Tingkah Laku Guru}

Guru menyampaikan semua tujuan pelajaran yang ingin dicapai pada pelajaran tersebut dan memotivasi siswa belajar.

Guru menyajikan informasi kepada siswa dengan jalan demonstrasi atau lewat bahan bacaan.

Guru menjelaskan kepada siswa bagaimana caranya membentuk kelompok belajar dan membantu setiap kelompok agar melakukan transisi secara efisien.

Guru membimbing kelompok-kelompok belajar pada saat mereka mengerjakan tugas-tugas mereka.

Guru mengevaluasi hasil belajar tentang materi yang telah dipelajari atau masing-masing kelompok mempersentasikan hasil kerjanya.

Guru mencari cara-cara untuk menghargai baik upaya maupun hasil belajar individu maupun kelompok.

Sumber: (Trianto, 2010)

Arahman dalam Hamdayama Jumanta (2014) snowball throwing adalah suatu model pembelajaran yang diawali dengan pembentukan kelompok yang diwakili

A. Mahera, N. Hermita, \& Lazim. N, Penerapan Model Pembelajaran Kooperatif Tipe Snowball Throwing untuk Meningkatkan Hasil Belajar IPS Siswa Kelas V SDN 161 Pekanbaru 
ketua kelompok untuk mendapat tugas dari guru, kemudian masing-masing siswa membuat pertanyaan di selembar kertas yang dibentuk seperti bola (kertas pertanyaan) lalu dilempar kesiswa lain. Siswa yang mendapat lembaran kertas harus menjawab pertanyaan dalam kertas yang diperoleh.

Snowball throwing adalah suatu cara penyajian bahan pelajaran dimana murid dibentuk dalam beberapa kelompok yang heterogen kemudian masing-masing kelompok dipilih ketua kelompoknya untuk mendapat tugas dari guru lalu masingmasing murid membuat pertanyaan yang dibentuk seperti bola (kertas pertanyaan) kemudian dilempar ke murid lain yang masing- masing murid menjawab pertanyaan dari bola yang diperoleh (Suprijono, 2011).

\section{Langkah-langkah model pembelajaran Kooperatif tipe snowball throwing:}

Langkah-langkah pembelajaran dalam melaksanakan model pembelajaran kooperatif tipe snowball throwing sebagaimana dikemukakan Hamdayama Jumanta (2014) sebagai berikut :

1. Guru menyampaikan materi yang akan disajikan, dan kompetensi dasar (KD) yang ingin dicapai

2. Guru membentuk siswa berkelompok, lalu memanggil masing-masing ketua kelompok untuk memberikan penjelaskan tentang materi yang telah di tentukan.

3. Masing-masing ketua kelompok kembali ke kelompoknya masing-masing, kemudian menjelaskan materi yang disampaikan oleh guru kepada temannya.

4. Kemudian masing-masing siswa diberi satu lembar kertas kerja, untuk menulis satu pertanyaan apa saja yang menyangkut materi yang sudah dijelaskan oleh ketua kelompok.

5. Kemudian kertas yang berisi pertanyaan tersebut dibuat seperti bola dan dilemparkan dari satu siswa ke siswa yang lain selama \pm 5 menit.

6. Setelah siswa mandapatkan satu bola/ satu pertanyaan diberikan kesempatan kepada siswa untuk menjawab pertanyaan yang tertulis dalam kertas berbentuk bola tersebut secara bergantian.

7. Evaluasi.

8. Penutup.

A. Mahera, N. Hermita, \& Lazim. N, Penerapan Model Pembelajaran Kooperatif Tipe Snowball Throwing untuk Meningkatkan Hasil Belajar IPS Siswa Kelas V SDN 161 Pekanbaru 
Hasil belajar adalah kemampuan-kemampuan yang dimiliki siswa setelah ia menerima pengalaman belajarnya (Sudjana Nana, 2005). Hasil belajar merupakan bagian terpenting dalam pembelajaran, adanya hasil belajar pada diri seseorang ditandai dengan adanya perubahan tingkah laku.

\section{METODE PENELITIAN}

Penelitian ini adalah penelitian tindakan kelas (PTK) yang dilakukan dikelas V.C SDN 161 Pekanbaru. Penelitian dilakukan pada semester ganjil 2018/2019 yang dilaksanakan pada tanggal 15 Agustus sampai tanggal 6 Sepetember 2018.

Menurut Arikunto (2015) Penelitian tindakan kelas adalah penelitian yang memaparkan terjadinya sebab-akibat dari perlakuan, sekaligus memaparkan apa saja yang terjadi ketika perlakuan diberikan, dan memaparkan seluruh proses sejak awal pemberian perlakuan sampai dengan dampak dari perlakuan tersebut. Yaitu dengan tahapan perencanaan, Tindakan, Pengamatan, dan Evaluasi dan Refleksi.

Subjek penelitian yaitu kelas V.C SDN 161 Pekanbaru sebanyak 30 orang terdiri dari 12 laki-laki dan 18 perempuan. Data dan instrumen adalah Silabus, RPP, LKS, Lembar Observasi Aktivitas Guru dan Siswa. Teknik pengumpulan data yaitu dengan Teknik observasi dan teknik tes.

\section{HASIL PENELITIAN}

Data penelitian ini adalah hasil belajar siswa yaitu hasil ulangan harian siklus I, ulangan harian siklus II, dan hasil observasi setiap pertemuan. Hasil tindakan yang dianalisis yaitu hasil belajar siswa setelah diterapkannya model pembelajaran. Data yang diperoleh dari hasil ulangan harian siklus I, ulangan harian siklus II, dan aktivitas guru dan siswa pada lembar observasi aktivitas guru dan siswa.

\section{Aktivitas Guru dan Siswa}

A. Mahera, N. Hermita, \& Lazim. N, Penerapan Model Pembelajaran Kooperatif Tipe Snowball Throwing untuk Meningkatkan Hasil Belajar IPS Siswa Kelas V SDN 161 Pekanbaru 
Menganalisis data dengan cara mengamati data tentang aktivitas guru dan siswa pada lembar pengamatan yang dilakukan secara bersamaan dengan kegiatan pembelajaran. Penilaian dilakukan oleh observer dengan menggunakan lembar observasi yang mengacu pada model. Pembelajaran yang meliputi kegiatan awal, kegiatan inti, dan kegiatan akhir. Hasil observasi aktivitas guru dan siswa dapat dilihat pada tabel 2 :

\section{Tabel 2}

Aktivitas Guru

\begin{tabular}{cllcll}
\hline No & Data & Pertemuan & Jumlah Skor & Persentase & Kategori \\
\hline \multirow{2}{*}{1} & Siklus I & Pertemuan 1 & 17 & $70,83 \%$ & Cukup \\
& & Pertemuan 2 & 19 & $79,16 \%$ & Baik \\
2 & \multirow{2}{*}{ Siklus II } & Pertemuan 3 & 20 & $83,33 \%$ & Baik \\
& & Pertemuan 4 & 21 & $87,5 \%$ & Sangat Baik
\end{tabular}

Berdasarkan tabel 2, terlihat aktivitas guru selama pembelajaran mengalami peningkatan. Aktivitas guru pada siklus I pertemuan 1, yaitu 70,83\% dengan kategori cukup. Hal ini dikarenakan guru masih belum mampu memfasilitasi siswa dengan baik. Pada siklus I pertemuan 2 mengalami peningkatan yaitu 79,16\% dengan kategori baik karena pada pertemuan ini guru sudah semakin baik dalam memfasilitasi siswa. Pada siklus II pertemuan 1, aktivitas guru meningkat lagi menjadi $83,33 \%$ dengan kategori baik. Pada siklus II pertemuan 2, proses pembelajaran sudah sangat bagus karena persentase aktivitas guru meningkat menjadi $87,5 \%$ dengan kategori sangat baik.

\section{Tabel 3}

\section{Aktivitas Siswa}

\begin{tabular}{|c|c|c|c|c|c|}
\hline No & Data & Pertemuan & Jumlah Skor & Persentase & Kategori \\
\hline \multirow{3}{*}{1} & \multirow{3}{*}{ Siklus I } & Pertemuan 1 & 14 & $58,33 \%$ & Kurang \\
\hline & & Pertemuan 2 & 16 & $66,66 \%$ & Cukup \\
\hline & & Pertemuan 3 & 19 & $79,16 \%$ & Baik \\
\hline 2 & Siklus II & Pertemuan 4 & 21 & $87,5 \%$ & Sangat Baik \\
\hline
\end{tabular}

Berdasarkan tabel 3, terlihat aktivitas siswa selama pembelajaran mengalami peningkatan. Aktivitas siswa pada siklus I pertemuan 1, yaitu $58,33 \%$ dengan kategori kurang. Hal ini dikarenakan siswa masih belum memahami langkahlangkah pembelajaran sehingga masih ada siswa yang bingung pada saat pembelajaran. Pada siklus I pertemuan 2 mengalami peningkatan yaitu $66,66 \%$ 
dengan kategori cukup karena pada pertemuan ini siswa sudah mulai bisa memahami langkah pembelajaran yang akan dilakukan. Pada siklus II pertemuan 1, aktivitas siswa meningkat lagi menjadi 79,16\% dengan kategori baik. Pada siklus II pertemuan 2, proses pembelajaran sudah sangat bagus karena persentase aktivitas siswa semakin meningkat menjadi $87,5 \%$.

\section{Peningkatan Hasil Belajar Siswa}

Setelah dilaksanakan pembelajaran dengan penerapan model pembelajaran kooperatif tipe snowball throwing pada siswa kelas V SDN 161 Pekanbaru dapat dilihat peningkatan hasil belajar siswa pada tabel 4 berikut ini.

Tabel 4

Peningkatan hasil belajar siswa

\begin{tabular}{|c|c|c|c|c|c|c|}
\hline \multirow[b]{2}{*}{ No } & \multirow[b]{2}{*}{ Tahapan } & \multirow{2}{*}{$\begin{array}{l}\text { Jumlah } \\
\text { siswa }\end{array}$} & \multirow{2}{*}{$\begin{array}{l}\text { Rata- } \\
\text { rata }\end{array}$} & \multicolumn{3}{|l|}{ Peningkatan } \\
\hline & & & & $\begin{array}{l}\text { Skor Dasar- } \\
\text { UH I }\end{array}$ & $\begin{array}{l}\text { Skor } \\
\text { UH II }\end{array}$ & Dasar- \\
\hline 1 & Skor Dasar & & 65,83 & & & \\
\hline 2 & Siklus I & 30 & 74,16 & $12,65 \%$ & $33,16 \%$ & \\
\hline 3 & Siklus II & & 87,66 & & & \\
\hline
\end{tabular}
meningkatkan hasil belajar IPS hal ini dapat kita lihat dari peningkatan nilai dari skor dasar hingga nilai ulangan harian II, adanya ketertarikan siswa untuk belajar karena guru menggunakan media pembelajaran dan menerapkan model pembelajaran yang relevan yang berpusat kepada siswa Sehingga siswa dapat belajar secara mandiri dan efektif untuk mengembangkan materi menggunakan peta konsep serta siswa dapat menerangkan materi melalui peta konsep kepada rekan-rekannya. Meningkatnya hasil belajar juga dipengaruhi dari meningkatnya jumlah siswa yang mengalami ketuntasan, sesuai dengan data pada tabel 5.

Tabel 5

Ketuntasan Hasil Belajar Siswa 


\begin{tabular}{|c|c|c|c|c|c|c|}
\hline \multirow[b]{2}{*}{ No } & \multirow[b]{2}{*}{ Tahapan } & \multirow[b]{2}{*}{$\begin{array}{l}\text { Jumlah } \\
\text { Siswa }\end{array}$} & \multicolumn{4}{|c|}{ Ketuntasan Klasikal } \\
\hline & & & $\begin{array}{l}\text { Siswa } \\
\text { Tuntas }\end{array}$ & $\begin{array}{l}\text { Siswa Tidak } \\
\text { Tuntas }\end{array}$ & $\begin{array}{l}\text { Persentase } \\
\text { Ketuntasan }\end{array}$ & Kategori \\
\hline 1 & $\begin{array}{l}\text { Skor } \\
\text { Dasar }\end{array}$ & & $\begin{array}{l}12 \\
(40 \%)\end{array}$ & $\begin{array}{l}18 \\
(60 \%)\end{array}$ & $40 \%$ & $\begin{array}{l}\text { Tidak } \\
\text { Tuntas }\end{array}$ \\
\hline 2 & Siklus I & 30 & $\begin{array}{l}19 \\
(63,33 \%)\end{array}$ & $\begin{array}{l}11 \\
(36,66 \%)\end{array}$ & $63,33 \%$ & $\begin{array}{l}\text { Tidak } \\
\text { Tuntas }\end{array}$ \\
\hline 3 & Siklus II & & $\begin{array}{l}26 \\
(86,66 \%)\end{array}$ & $\begin{array}{l}4 \\
(13,33 \%)\end{array}$ & $86,66 \%$ & Tuntas \\
\hline
\end{tabular}

\section{Skor perkembangan Individu dan Penghargaan Kelompok}

Skor perkembangan individu dan penghargaan kelompok dapat diamati pada tabel 6 berikut ini:

Tabel 6

Nilai Perkembangan Individu Siklus I Dan Siklus II

\begin{tabular}{lllll}
\hline \multirow{2}{*}{ Skor Perkembangan } & Siklus I & & Siklus II & \\
\cline { 2 - 5 } & P1 & P2 & P1 & P2 \\
\hline 1 Poin & 2 & 3 & 3 & 2 \\
10 Poin & 6 & - & - & - \\
20 Poin & 15 & 16 & 12 & 12 \\
30 Poin & 4 & 6 & 7 & 3 \\
30 Poin & 3 & 5 & 8 & 13 \\
Jumlah siswa & 30 & 30 & 30 & 30 \\
\hline
\end{tabular}

Tabel 7

Penghargaan Kelompok

\begin{tabular}{|c|c|c|c|c|}
\hline Prediket & & & Sikl & \\
\hline & P1 & $\mathrm{P} 2$ & $\mathrm{P} 1$ & $\mathrm{P} 2$ \\
\hline Tim Baik & 2 & 1 & - & - \\
\hline Tim Hebat & 4 & 4 & 4 & 2 \\
\hline Tim Super & - & 1 & 2 & 4 \\
\hline
\end{tabular}

\section{PEMBAHASAN HASIL PENELITIAN}

Berdasarkan hasil penelitian yang dilakukan mengalami peningkatan pada aktivitas guru. Pada pertemuan pertama siklus dengan persentase 70,83\% dikategorikan cukup dan pertemuan kedua dengan persentase $79,16 \%$ kategori baik. Pada siklus kedua pertemuan pertama dengan persentase $83,33 \%$ kategori baik. Pada pertemuan kedua dengan persentase $87,5 \%$ dikategorikan sangat baik.

A. Mahera, N. Hermita, \& Lazim. N, Penerapan Model Pembelajaran Kooperatif Tipe Snowball Throwing untuk Meningkatkan Hasil Belajar IPS Siswa Kelas V SDN 161 Pekanbaru 
Aktivitas siswa juga mengalami peningkatan dapat dilihat pada aktivitas siswa pada siklus 1 pertemuan pertama didapat persentase 58,33\% dengan kategori kurang sedangakan pertemuan kedua mengalami peningkatan yaitu dengan persentase $66,66 \%$ dengan kategori cukup. Pada sikuls 2 pertemuan pertama didapat persentase $79,16 \%$ kategori baik. Kemudian pada pertemuan kedua mengalami peningkatan dengan persentase $87,5 \%$ dengan kategori sangat baik

Hasil belajar IPS sebelum diberikan tindakan yaitu 65,83 pada ulangan harian siklus I nilai rata-rata yaitu 74,16 dengan peningkatan sebesar $12,65 \%$. Rata-rata ulangan harian siklus II yaitu 87,66 mengalami peningkatan sebesar $33,16 \%$.

\section{SIMPULAN}

Berdasarkan hasil analisis dan penelitian peningkatan dapat dilihat pada aspek berikut:

1. Aktivitas guru pertemuan I siklus I persentase $70,83 \%$ Pada pertemuan II siklus I meningkat dengan persentase $79,16 \%$ Sedangkan pada pertemuan I siklus II dengan persentase $83,33 \%$ dan pada pertemuan II siklus II meningkat lagi persentase $87,5 \%$ sedangkan Aktivitas siswa mengalami peningkatan pada setiap pertemuan, dibuktikan dengan pertemuan I siklus I persentase $58,33 \%$ pertemuan II siklus I meningkat dengan persentase $66,66 \%$, Sedangkan pada pertemuan I siklus II dengan persentase $79,16 \%$, dan pertemuan II siklus II meningkatkan dengan persentase $87,5 \%$.

2. Nilai rata-rata hasil belajar IPS meningkat, hal ini dapat dilihat dari nilai skor dasar dengan rata-rata 65,83 sedangkan nilai rata-rata ulangan harian I adalah 74,16. Peningkatan nilai dari skor dasar ke ulangan harian I meningkat $12,65 \%$. Sedangkan nilai rata-rata ulangan harian II adalah 87,66 persentase peningkatan dari skor dasar ke ulangan harian II adalah $33,16 \%$.

Berdasarkan hasil penelitian, pembahasan dan simpulan sebagaimana diuraikan diatas maka penelit mengajukan beberapa rekomendasi yang 
berhubungan dengan penerapan model pembelajaran kooperatif tipe snowball throwing dalam pembelajaran yang mampu mampu meningkatkan kualitas dan efektivitas belajar siswa yaitu:

1. Penerapan model pembelajaran kooperatif tipe snowball throwing menjadikan siswa lebih memahami materi, lebih aktif dalam pembelajaran, dan mampu menjadi facilitator terhadap rekan-rekannya.

2. Model pembelajaran kooperatif tipe snowball throwing dalam pelaksanaan pembelajaran berpusat kepada siswa.

3. Penerapan Model pembelajaran kooperatif tipe snowball throwing dapat dijadikan sebagai model pembelajaran di SDN 161 Pekanbaru karena hasil penelitian penerapan model pembelajaran kooperatif tipe snowball throwing dapat meningkatkan hasil belajar serta meningkatkan keaktifan dan peranan siswa dalam proses pembelajaran.

\section{DAFTAR PUSTAKA}

Hamdayama, J. 2014. Model dan Metode Pembelajaran Kreatif dan Berkarakter.

Bogor: Ghalia Indonesia.

Isjoni. 2016. Pembelajaran Kooperatif. Yogyakarta: Pustaka Pelajar.

Sudjana, N. 2005. Penilaian Hasil Proses Belajar Mengajar. Bandung: PT. Remaja Rosdikarya. hlm. 22.

Suharsimi dkk. 2015. Penelitian Tindakan Kelas. Jakarta: Bumi Aksara.

Suprijono, A. 2011. Cooperatif Learning Teori dan Aplikasi PAIKEM. Yogyakarta:

Pustaka Belajar.

Trianto. 2010. Model Pembelajaran Terpadu. Jakarta: Kencana.

Vidianawati dkk. 2014. Penerapan Model Pembelajaran Kooperatif Tipe Snowball

Throwing Terhadap Hasil Belajar Stuktur Atom Kelas X di SMA Negeri 1

Marawola. J. Akad. Kim. 3(1): 42-49. Pendidikan Kimia FKIP, Universitas

Tadulako. Palu. (Online). (diakses 7 Oktober 2018).

Yusuf dkk. 2017. Penerapan Model Pembelajaran Kooperatif Tipe Snowball

Throwing Terhadap Hasil Belajar Peserta Didik. Vol 2, No. 1. FKIP UNIPA, Manokwari. Manokwari. (Online). (diakses 12 September 2018). 